CZASOPISMO INŻYNIERII LACDOWEJ, ŚRODOWISKA I ARCHITEKTURY JOURNAL OF CIVIL ENGINEERING, ENVIRONMENT AND ARCHITECTURE

JCEEA, t. XXXII, z. 62 (1/15), styczeń-marzec 2015, s. 409-417

\author{
Marek URBANIK ${ }^{1}$ \\ Barbara TCHÓRZEWSKA-CIEŚLAK ${ }^{2}$
}

\title{
ECOLOGICAL ASPECTS \\ OF THE NATURAL GAS USE
}

\begin{abstract}
Good alternative for diesel fuel and petrol is gas. It is about half the price of diesel and fuel-powered vehicles and emit significantly less harmful compounds in exhaust gases, eg. $\mathrm{CO}_{2}$ emissions are reduced by approx. 10-15\%. For the introduction of natural gas as fuels used to power vehicles and installations supports also one argument, in the twentieth century, energy consumption has increased more than fifteen times, while fossil fuels like coal, oil, natural gas is the main source of energy. According to the International Energy Agency, transportation as one of the fast growing sectors of the economy consumes approx. $26 \%$ of the main sources of energy, especially oil, which deposits are of successively depletion. If oil consumption will grow at the same rate as before, then how provide forecasts to meet the needs of the world of vehicles fleet for the use of only petroleum fuelsit will be impossible for approx. twenty years and the other power technologies (eg. hydrogen fuel) are not yet refined. Natural gas may therefore be called as transition fuel between oil fuels and other technologies to power vehicles or installations.
\end{abstract}

Keywords: natural gas, regulation of natural gas use, airpollution

\section{Introduction}

Environmental policy is one of the most important priorities of the European Union, while natural gas isthe most environmentally friendly fossil fuel and takes more and more place in the EU's policy on fuel.

Installations and vehicles powered by natural gas are treated in the European Union very prospectively. Among them are either industrial installations, heating systems, cars, vans and large trucks and buses $[1,8,12]$. The main factor of such actions is the ecological aspect of the natural gas use as a fuel, as well as the same price of natural gas compared to gasoline or diesel [16]. To the increasing popularity of this fuel also contribute governments especially of Western Europe which encourage the use of natural gas through special tax preferences.

\footnotetext{
${ }^{1}$ Autor do korespondencji/corresponding author: Marek Urbanik, Rzeszow University of Technology, Powstańców Warszawy 6, 35-959 Rzeszow, marekurbanik@vp.pl

${ }^{2}$ Barbara Tchórzewska-Cieślak, Rzeszow University of Technology
} 


\section{European Union policy regarding the use of natural gas}

Directive in many areas leave the countries of the European Union the choice of solutions, however, while maintaining comparable effects on key issues, which include the scope of opening up national markets to international competition. Regarding the natural gas market in the European Union, the basic directive governing this segment of the market is the European Gas Directive. It consists of the following acts:

- Council Directive 91/296/EEC of 31 May 1991, on the transit of natural gas through a network,

- Regulation 1775/2005 of the European Parliament and the Council of 28 September 2005, on conditions for access to the transmission networkof natural gas,

- Directive 2003/55/EC of the European Parliament and the Council of 26 June 2003, concerning common rules for the internal market in natural gas and repealing Directive 98/30/EC,

- Directive 98/30/EC of the European Parliament and the Council of 22 June 1998, concerning common rules for the internal market in natural gas.

At the end of 2001 the European Commission presented a proposal for the two Directives relating to biomass fuels where biofuels together with natural gas and hydrogen were classified as the most important alternative fuels. In 2003, the European Parliament adopted Directive 2003/30/EC, that obliged member states of the European Union to increase the use of clean fuels. According to the ENGVA (European Natural Gas Vehicle) by 2020, it is planned to replace the organic fuels to $23 \%$ of traditional fuels, as petrol and diesel in the transport sector, treating the compressed natural gas as an excellent substitute for conventional fuel, equally with renewable fuels [7].

The European Union has launched a range of support systems that enable the implementation of the implementation of projects promoting the use of natural gas as a fuel to power vehicles. Organizations that deal with these types of subsidies are m.in.:

- European Cohesion Fund,

- Structural Funds - Sectoral Operational Programme - Improvement of the Enterprises Competitiveness,

- Financial Mechanism of the European Economic Area and Norwegian Financial Mechanism.

The main impetus of such actions is the ecology and also economic factor has considerable influence, because natural gas is a cheaper than fuel compared to other fuels. 


\section{Environmental aspects of the natural gas use}

There is no doubt about the effects of large amounts combustion of fuel on Earth. Related tothis is the increase in the average temperature of the earth's atmosphere, slowly progressing great masses of ice melting on the globe, noticeably increases of the sea levels. The main reason for this is constantly rising carbon dioxide emissions, which largely comes from fuel combustion. No complete combustion and processes result the entry into the atmosphere of methane, propane, butane and other hydrocarbons. Additionally, there is a sulfur fuels which, when burned give sulfur dioxide [3,9]. A significant increase in the number of vehicles causes, especially in large cities, the rapid deterioration of air quality. Coming to this the growth of transit traffic causes an increase in the emission of communicationpollutants [15]. Related to this issue is also smog, which is known as smog winter (caused by emissions from diesel engines). US Environmental Protection Agency lists natural gas as fuel relatively cleanest and safest. The use of natural gas as a fuel for motor vehicles especially in urban areas where air is highly polluted is significant and turns out to be highly desirable. It should be noted that pollution is not only the exhaust gasof engine, but also:

- effect of fuel evaporation and emissions from fuel tanks,

- emissions after the engine stops (cooling process),

- fuel emissions when filling tank.

Worldwide communication is based primarily on petrol and diesel, while wear enormous, until recently, the amount of tetraethyl lead added to gasoline. Recent years have effectivelystruggle for elimination of the gasoline additive and the use of better catalysts [10]. It was found that global emissions produced by vehicles has become a menace to society and the environment. The struggle for the reduction of toxic compounds emissions found on the banners of many communities that have requested the use of fuels that emit "clean" exhaust [13].

Research on use of gas into the drive vehicle are carried out for a long time, practically all over the world. One of the main reasons is probably ecology, since as can be seen from table 1 natural gas is the fuel that emits minimum toxic compounds in comparison with other fuels. These studies focused mainly on liquid propane, propane-butane mixture (LPG), compressed natural gas (CNG) and liquefied (LNG) and compressed hydrogen and liquefied [5, 14].

From the perspective of environmental protection particularly high risk gives emissions associated with the operation of road transport. Table 2 shows the emission of air pollutants from road transport in Poland in 2003. By contrast, in fig. 1 increased $\mathrm{CO}_{2}$ emissions is seen from road transport in the years 1990 to 2004 in the 25 EU countries and in Bulgaria, Iceland, Norway, Romania and Turkey $[2,4]$. 
Table 1. Pollutant emissions distance traveled by cars powered by different fuels ${ }^{1}$ developed, based on [11]

Tabela 1. Emisja zanieczyszczeń z samochodów napędzanych różnymi paliwami, na podstawie [11]

\begin{tabular}{|c|c|c|c|c|c|}
\hline \multirow{2}{*}{ Pollution } & \multicolumn{5}{|c|}{ Emission ranges [g/km] with power motors by different fuels } \\
\cline { 2 - 6 } & gasoline & $\begin{array}{c}\text { gasoline (with } \\
\text { catalytic after } \\
\text { combustion) }\end{array}$ & CNG & ON & CNG + ON \\
\hline Carbon monoxide & $2,5-10,0$ & $1,0-2,5$ & $0,5-1,5$ & $0,2-1,0$ & $0,2-1,0$ \\
\hline Nitrogen oxides & $1,0-1,8$ & $0,25-0,45$ & $0,5-0,9$ & $0,5-1,8$ & $0,5-1,8$ \\
\hline $\begin{array}{c}\text { Hydrocarbons (exclu- } \\
\text { ding methane) }\end{array}$ & $1,0-2,0$ & $0,1-0,2$ & $0,10,2$ & $0,1-0,2$ & $0,1-0,2$ \\
\hline Soot & - & - & - & $4-40$ & $2-15$ \\
\hline
\end{tabular}

${ }^{1}$ While maintaining comparability due to the same test

Table 2. The level of pollutant emissions from road transport in Poland

Tabela 2. Poziom emisji zanieczyszczeń z transportu drogowego w Polsce

\begin{tabular}{|c|c|}
\hline Emission type & Emission in tonnes \\
\hline Carbon dioxide & 28989 \\
\hline Methane & 4,2 \\
\hline Nitrous oxide & 1,94 \\
\hline Carbon monoxide & 609,3 \\
\hline Non-methane volatile organic compounds & 111,1 \\
\hline Nitrogen oxides & 234,5 \\
\hline Particles & 14,94 \\
\hline Sulphur dioxide & 2,52 \\
\hline Lead & 0,021 \\
\hline
\end{tabular}

As you can see, these values are very high and, therefore, for environmental reasons, it is appropriate to introduce alternative gaseous fuels. These activities are still limited in scope due to such difficulties, which mainly arise from:

- lack of adequate infrastructure - this is due to the fact that there is still little knowledge of the public on these fuels, which involves little interest and the company responsible for the supply of gas not conduct activities related to its construction and development,

- sufficient discernment on the part of local and regional authorities regarding the advantages of gas-friendly to the environment, especially when the gas is used to drive public transport and municipal vehicles.

Despite these difficulties, gaseous fuels, which are very interesting alternative to liquid fuels, among other things, due to the emission of toxic exhaust, significantly lower engine noise and their price, are finding increasing use in road transport. The possibility of overcoming these difficulties is the propanebutane (LPG), which is a result of interest on the part of users of private vehi- 
cles, as well as infrastructure development and favorable relationships prices compared to conventional fuel, has found its permanent position in the fuel market in the last ten years [5]. The sum of the pollutants emitted by engines powered by compressed natural gas is several times lower in comparison with diesel engines so that $\mathrm{CNG}$ is the only conventional fuel currently meets all current and future emission standards provided for by the European Union (fig. 2).

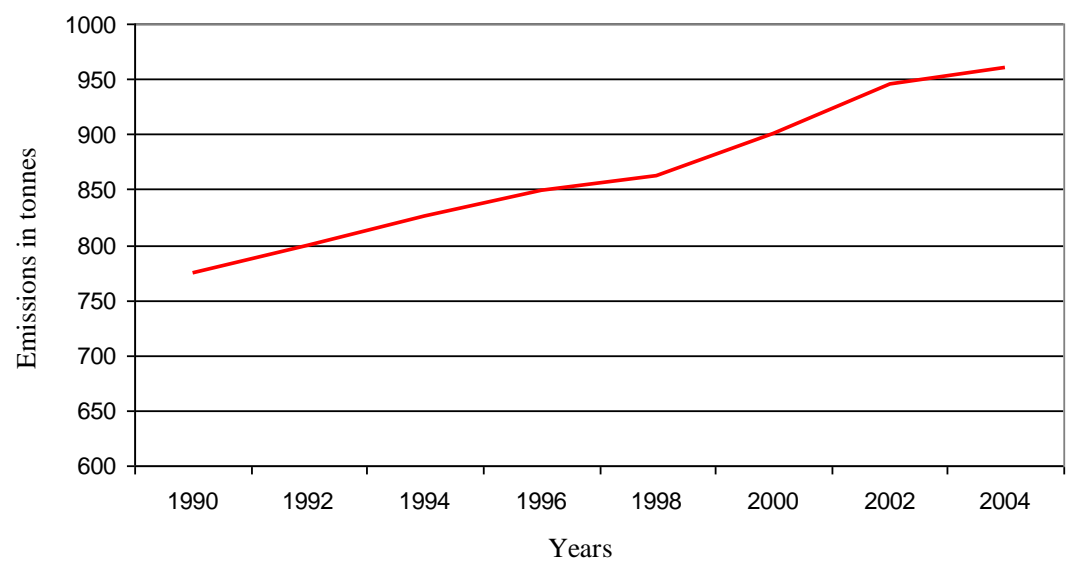

Fig. 1. $\mathrm{CO}_{2}$ emissions from road transport in the $25 \mathrm{EU}$ countries and in Bulgaria, Iceland, Norway, Romania and Turkey

Rys. 1. Emisja $\mathrm{CO}_{2}$ z transportu domowego w 25 krajach UE oraz w Bułgarii, Islandii, Norwegii, Rumunii i Turcji

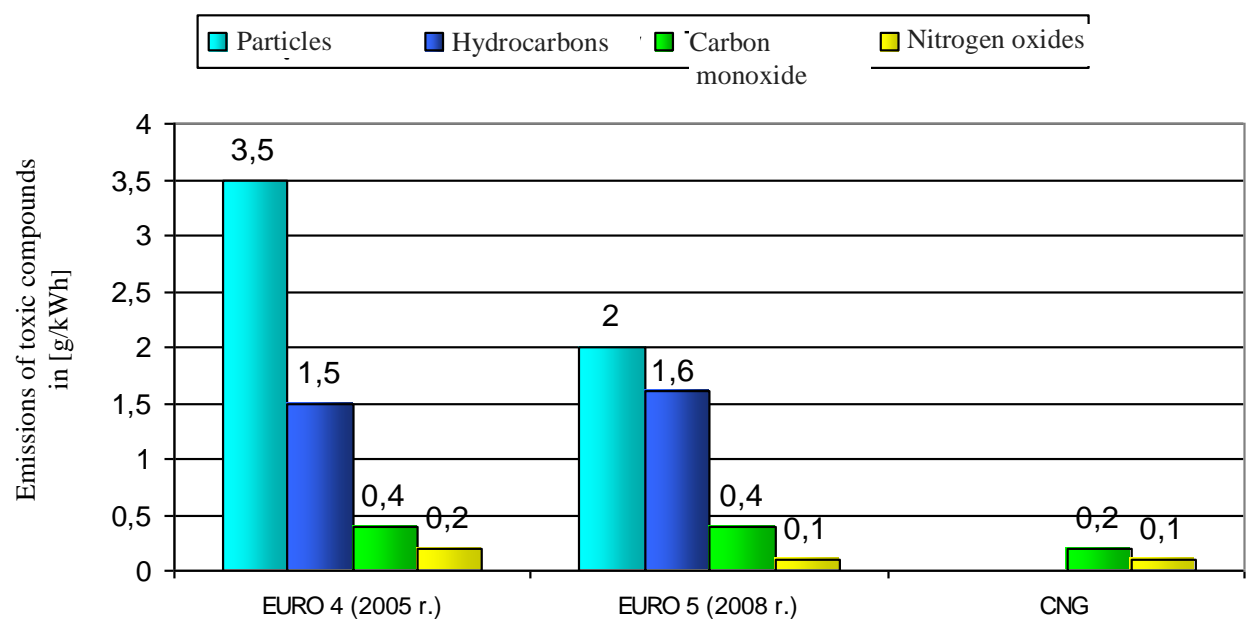

Fig. 2. European emission standards for toxic substances from internal combustion engines and emissions of toxic substances from modern engines CNG developed, based on [5]

Rys. 2. Europejskie normy emisji dla substancji toksycznych z silników spalinowych oraz emisji substancji toksycznych z nowoczesnych silników CNG, na podstawie [5] 
In the combustion of natural gas is a significant reduction in carbon dioxide $\left(\mathrm{CO}_{2}\right)$, nitrogen oxides (NOx), sulfur oxides ( $\left.\mathrm{SOx}\right)$, and above all particles. The reduction of pollutants emitted by vehicles powered by natural gas to petrol and diesel are shown in fig. 3-4. In addition, the exhaust gas from natural gas engines are far less carcinogens, which directly affects the health of society. Using natural gas also reduces the noise level of the vehicle from 2 to $4 \mathrm{~dB}$. This means in practice that at a distance of $7 \mathrm{~m}$ from the passing vehicle noise is reduced by approx. $40 \%$. This is important especially in urban areas with heavy traffic vehicles [7].

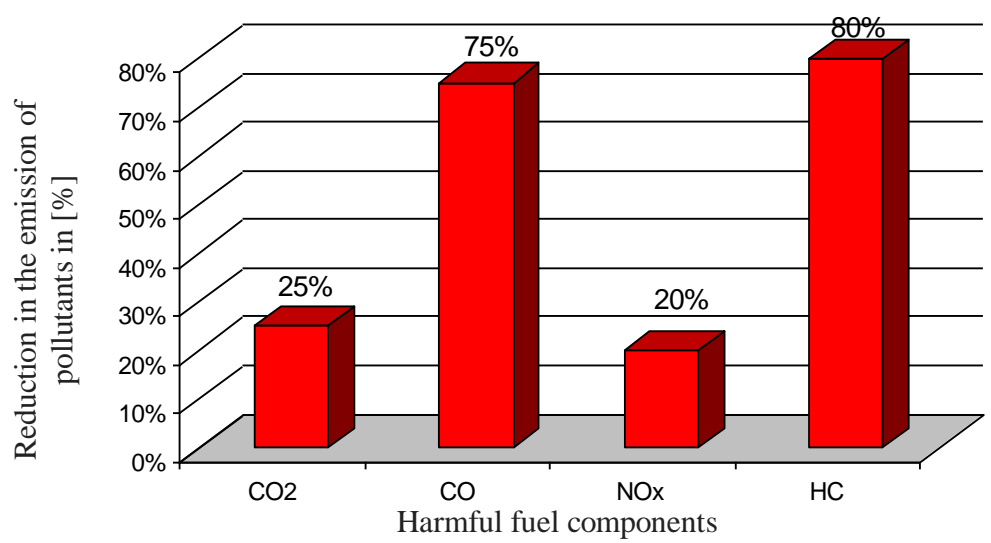

Fig. 3. Reduction of pollutant emission $[\mathrm{g} / \mathrm{km}]$ of passenger vehicles $\mathrm{CNG}$ in comparison to petrol, based on [7]

Rys. 3. Ograniczenie emisji zanieczyszczeń w samochodach osobowych zasilanych CNG w porównaniu z zasilanymi benzyną, na podstawie [7]

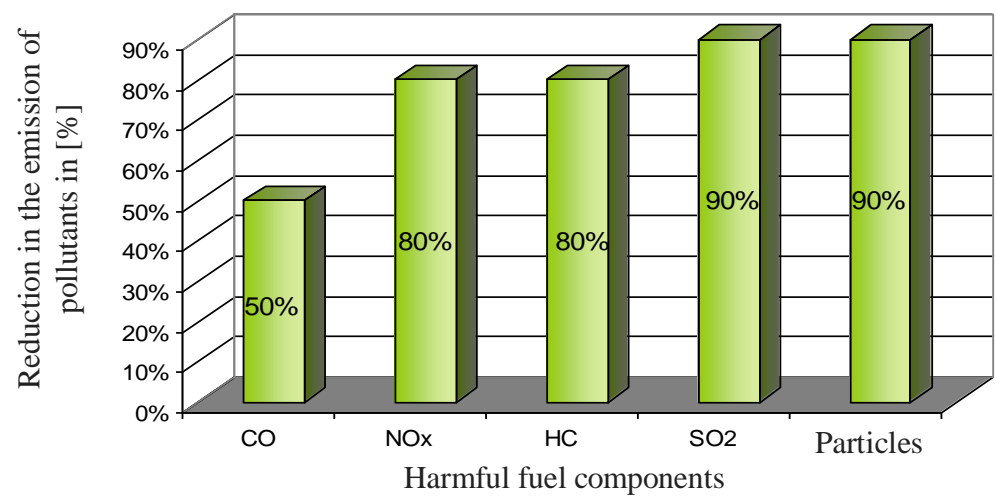

Fig. 4. Reduction of pollutant emission $[\mathrm{g} / \mathrm{km}]$ passenger vehicles powered by CNG for diesel fuel developed, based on [7]

Rys. 4. Ograniczenie emisji zanieczyszczeń w samochodach osobowych zasilanych CNG w porównaniu z zasilanymi olejem napędowym, na podstawie [7] 
A recent study by Elpigaz using CNG as fuel confirm the ecological advantages of this type of fuel (fig. 5). The test was performed on Opel Astra 1.6 $\mathrm{dm}^{3}$ of a motor equipped with a sequential injection CNG-"ELISA M".

The results were compared with emissions standards Euro 3, which was subject to vehicle. As can be seen from a comparison engine that gasoline meets the standard EURO 3 powered by natural gas meets the requirements of the standard Euro 4 and can already meet the requirements standards EURO 5.

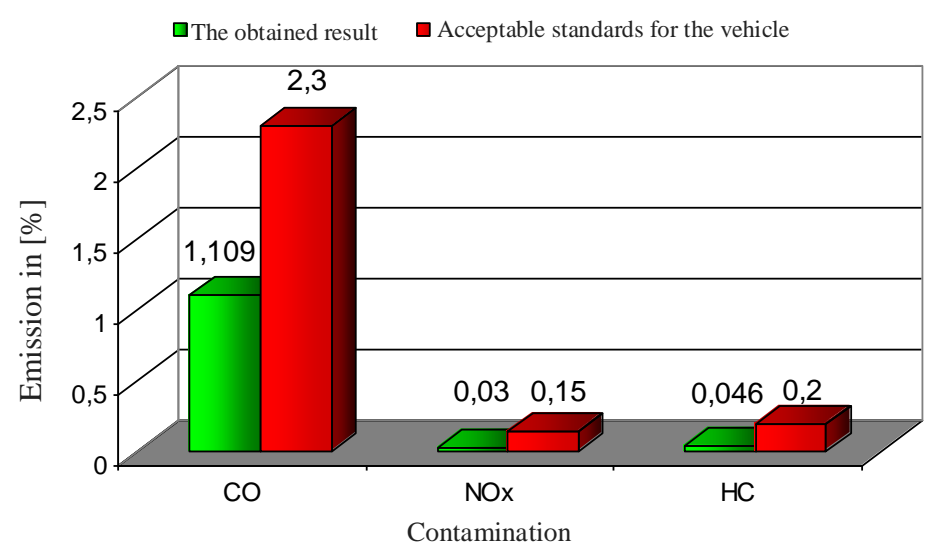

Fig. 5. Results of the exhaust emission test for Opel Astra with an engine capacity of $1.6 \mathrm{dm}^{3}$ powered by CNG, based on [6]

Rys. 5. Wyniki testu emisji spalin dla Opla Astry z silnikiem o pojemności $1.6 \mathrm{dm}^{3}$ zasilanego $\mathrm{CNG}$, na podstawie [6]

Progressive environmental pollution negatively affects not only our health (pollution contribute to the development of cancer), but also on climate change - ozone depletion in the atmosphere, leading to more frequent disasters occurring in the world (heat, drought, floods, hurricanes, blizzards). Changing supply of natural gas vehicles is therefore supremely desirable for society [6].

\section{Conclusion}

In our country consumed natural gas in $70 \%$ is imported, of which the largest supplier Russia supplies approx. 80\% of imported natural gas. In this way, the supply of natural gas to the Polish practically depend on a single supplier. Therefore, the Polish government has to consider the need for diversification of natural gas supplies. For this purpose, it is planned to construction of a liquefied gas terminal at Swinoujscie where the gas will be supplied by sea. The next action in this direction will be to increase domestic production and development of gas storage facilities. If these assumptions are made, it will lead to increase secu- 
rity of natural gas supply as well as to maintain its prices at a level to supply natural gas vehicles was profitable.

Regard for continuous growing importance of environmental policy one should not forget about the economic aspects, especially now with the growing competition. Many transport companies as to be competitive in relation to other market participants seek to reduce prices of the services provided by reducing the costs associated with their implementation. Practically most of the costs associated with the implementation of this transport means incurred for the purchase of fuel for powering vehicles. Today, more and more enterprises to reduce expenditures on fuel supply start their vehicles with natural gas. For its application supports not only low price but also the environmental aspect because it is the cleanest fuel from the fuel used so far on a wider scale.

\section{Bibliography}

[1] Bartłomiejczyk G.: Pojazd a środowisko. V Ogólnopolska Konferencja NaukowoTechniczna. Materiały z Zakładu Gazowniczego w Rzeszowie, Rzeszów 2007.

[2] Bielski J.: Rozwój globalnego handlu gazem LNG. Już nie tylko Azja. Nafta \& Gaz Biznes, 04.05.2005.

[3] http://www.gazziemny.pl/79.htm

[4] http://www.lanckoronska.eu/?a=koalicja.broszuras_03

[5] http://www.metan.pl/main.html

[6] http://www.n.elpigaz.com/?p=/pl/menu/5/2/3

[7] http://www.psgaz.pl/dla_pojazdow/

[8] Janic M.: Estimating the long-term effects of different passenger car technologies on energy/fuel consumption and emissions of greenhouse gases in Europe. Transportation Planning and Technology, no. 37(5), 2014, pp. 409-429.

[9] Johansson B.: The economy of alternative fuels when including the cost of air pollution. Transportation Research Part D-Transport and Environment, no. 4(2), 1999, pp. 91-108.

[10] Mbarawa M.: Performance, emission and economic assessment of clove stem oildiesel blended fuels as alternative fuels for diesel engines. Renewable Energy, no. 33(5), 2008, pp. 871-882.

[11] Molenda J., Steczko K.: Ochrona środowiska w gazownictwie i wykorzystanie gazu. WNT, Warszawa 2000.

[12] Samara Z., Heldt C.: Global emissions from road transport. Proc. of $3^{\text {rd }}$ GEIA Worshop. Amersfort, Netherlands 1993.

[13] Samaras Z., Zachariadis T.: Modeling the emission of road vehicles at macroscale and microscale, [in:] Air pollution emissions inventory, vol. 3, Power H., Babdasano J.M. (eds.). Souhampton U.K. and Boston, USA 1998.

[14] Van Vliet O., Brouwer A.S., Kuramochi T.: Energy use, cost and $\mathrm{CO}_{2}$ emissions of electric cars. Journal of Power Sources, no. 196(4), 2011, pp. 2298-2310.

[15] Wang G., Ogden J.M., Sperling D.: Comparing air quality impacts of hydrogen and gasoline. Transportation Research. Part D: Transport and Environment, no. 13(7), 2008, pp. 436-448. 
[16] Zhang Y., Chen B.S., Liu G.Q.: Natural gas and indoor air pollution: A comparison with coal gas and liquefied petroleum gas. Biomedical and Environmental Sciences, no. 16(3), 2003, pp. 227-236.

\section{EKOLOGICZNE ASPEKTY STOSOWANIA GAZU ZIEMNEGO}

Streszczenie

Alternatywą dla oleju napędowego i benzyny jest gaz ziemny będący o połowę tańszy od oleju napędowego. Instalacje oraz pojazdy zasilane tym paliwem emitują znacznie mniej szkodliwych związków w spalinach, np. emisja $\mathrm{CO}_{2}$ jest mniejsza o około 10-15\%. Za wprowadzeniem gazu ziemnego do grupy paliw stosowanych przemawia jeszcze jeden argument. W XX wieku zużycie energii wzrosło ponadpiętnastokrotnie. Paliwa kopalne, takie jak: węgiel, ropa naftowa, gaz ziemny, stanowią główne źródła energii. Jak podaje Międzynarodowa Agencja Energii, transport jako jedna z szybko rozwijających się gałęzi gospodarki zużywa ok. 26\% głównych źródeł energii, przede wszystkim ropy naftowej, której złoża ulegają sukcesywnemu wyczerpywaniu. Jeżeli zużycie ropy naftowej będzie tak intensywnie wzrastało, to - jak przewidują prognozy - zaspokojenie potrzeb światowej floty pojazdów przy korzystaniu tylko z paliw ropopochodnych za około 20 lat będzie niemożliwe. Inne technologie zasilania (np. paliwem wodorowym) nie są też do końca dopracowane. Gaz ziemny może być zatem tzw. paliwem przejściowym pomiędzy paliwami ropopochodnymi a innymi technologiami zasilania pojazdów bądź instalacji.

Słowa kluczowe: gaz ziemny, regulacje stosowania gazu naturalnego, zanieczyszczenie powietrza

Przestano do redakcji: 11.07.2014 $r$.

Przyjęto do druku: 28.03.2015 r.

DOI: $10.7862 / \mathrm{rb} .2015 .29$ 
